\title{
Firm History and Managerial Entrenchment: Empirical Evidence for Vietnam Listed Firms
}

\author{
Lan Le-Phuong Pham ${ }^{1}$, Duc Hong Vo ${ }^{1,2}$, Thang Cong Nguyen ${ }^{1}$ and Michael McAleer ${ }^{2-6, *}$ \\ ${ }^{1}$ Business and Economics Research Group, Ho Chi Minh City Open University, Vietnam \\ ${ }^{2}$ Department of Finance, Asia University, Taiwan \\ ${ }^{3}$ Discipline of Business Analytics, University of Sydney Business School, Australia \\ ${ }^{4}$ Econometric Institute, Erasmus School of Economics, Erasmus University Rotterdam The Netherlands \\ ${ }^{5}$ Department of Economic Analysis and ICAE, Complutense University of Madrid, Spain \\ ${ }^{6}$ Institute of Advanced Sciences, Yokohama National University, Japan
}

\begin{abstract}
Managerial entrenchment occurs when managers are able to manipulate financing decisions to support their own interests rather than those of shareholders. Such possible actions can involve deception and fraud. Furthermore, the market timing activity is explained by managers' financing decisions through which companies choose to raise debt or equity to finance their investment opportunities. Nevertheless, the relationship between managerial entrenchment and leverage ratio, together with the link between market timing and leverage ratio, have not been considered carefully and investigated in the Vietnamese context. The paper provides empirical evidence of the effect of managerial entrenchment and market timing through firms' histories on leverage ratio in Vietnam using a sample of 289 non-financial firms listed on the Ho Chi Minh Stock Exchange (HOSE) during the period 2006-2017. OLS, GMM and the endogenous switching methods are used for estimating the models. Findings from the paper indicate that there is a negative relationship between managerial entrenchment and leverage ratio, and that there is a negative effect of firm history, including financial deficit, various timing measures, and stock price history on the leverage ratios of Vietnam's listed firms.
\end{abstract}

Keywords: Managerial entrenchment, Firm histories, Leverage ratio, Endogenous switching, HOSE.

\section{INTRODUCTION}

Corporate governance principles provide the structure for firms to achieve their objectives, and to shape instruments to control firm performance. Theoretical foundations and empirical evidence indicate that strong corporate governance successfully promotes the success of firms in both management and finance (OECD, 2015). Within the corporate governance framework, the relationship between managerial entrenchment and the leverage ratio has attracted great attention from academia, practitioners, and public policy makers.

According to Berger, Ofek and Yermack (1997), managerial entrenchment occurs when managers fail to experience corporate governance discipline, and manipulate financing decisions to support their own interests rather than those of shareholders. Such possible actions can involve deception and fraud. The impact of managerial entrenchment and market timing behaviour on the leverage ratio has not been carefully investigated. The market timing activity is explained by managerial decisions through which companies choose to raise debt or equity to support their investment strategies.

\footnotetext{
*Address correspondence to this author at the Department of Finance, Asia University, Taiwan; Tel: 2332-3456\#1837;

E-mail: michael.mcaleer@gmail.com

JEL: C24, G32
}

Entrenched managers tend to issue substantial amounts of equity when the equity market is more favourable (Graham and Harvey 2001). Baker and Jeffrey (2002) define capital structure as the cumulative outcome of past attempts to time the equity market. Kayhan and Titman (2007) find that firm history, such as timing measures and stock price returns, play crucial roles in determining the leverage ratio. Thus, managerial entrenchment and market timing behaviour should be simultaneously examined. This is undertaken in the present paper.

In Vietnam, few studies have examined the influence of managerial entrenchment and the market timing effect via firm history on the leverage ratio. There is lack of empirical evidence analyzing the market timing effect on the leverage ratio, although many studies have applied the trade-off versus the pecking order theories (see, for example, Vo and Nguyen (2015)). As the Vietnam securities market has reached an early stage of development, information asymmetry and agency problem may occur.

Firms have considerable difficulty in predicting current trends in the stock market and determining an optimal leverage level. Nguyen (2015) indicates that past stock price is an important factor explaining market timing behaviour. However, managerial entrenchment and firm history have been ignored in this analysis. Hence, this paper provides empirical evidence on the above issues, which have been 
ignored in previous empirical studies in the Vietnamese context.

The plan of the remainder of the paper is as follows. The literature review and empirical studies are analyzed in Section 2. The data, methodology and model specifications are given in Section 3, including the two-stage approach for estimating the target leverage ratios, and the endogenous switching regression model for the high and low entrenchment regimes. The empirical results are evaluated in Section 4. Concluding remarks and public policy recommendations are presented in Section 5.

\section{LITERATURE REVIEW AND EMPIRICAL STUDIES}

In their seminal paper, Jensen and Meckling (1976) develop agency theory that indicates agency conflicts between shareholders and top managers. The conflicts primarily result from the separation of ownership and control. Managers are responsible for maximizing shareholder wealth. However, the best interests of shareholders are not always be achieved by top managers. Such possible actions can involve deception and fraud.

Shareholders protect their interests by providing managers with incentives. First, encouragement is related to an increase in managerial ownership. Nonetheless, once holding such a considerable power, managers fail to experience corporate governance mechanisms, thereby causing managerial entrenchment (see, for example, Berger, Ofek and Yermack, 1997). Entrenched managers have a tendency to use their privileged positions to manipulate firm investment opportunities and preserve their well-being (see, for example, Morck, Shleifer and Vishny, 1988).

Second, stimulation exists in the form of an escalation in the debt level (Grossman and Hart, 1983; Jensen, 1986). Debt financing seems to be a powerful "penalty" in mitigating managers' from satisfying empire building (Hart, 1995). According to signaling theory, agency conflicts also result from asymmetric information between insiders and outsiders. Managers are supposed to obtain more information about firm investment opportunities than investors (Ross, 1977). Outsiders try their best to obtain the information from a variety of sources. In truth, permission to access the real value of present and future investment of firms is limited. Moreover, the reliability of information needs verification. Investors are likely to subject changes made by managers to careful scrutiny.

A modification of capital structure leads to an alteration of firm performance. When the debt level is boosted, outsiders receive a signal that the promise of high future cash flows are expected (Ross, 1977). On the contrary, as firm investment is financed with new equity issuing, outsiders will perceive the firm performance to be declining. Current investors have to share losses with newcomers.

Based on the study of Grossman and Hart (1983), Berger et al. (1997) recommend managerial entrenchment and capital structure theory to predict firm efficiency when firms are dealing with agency problems. The theory also sheds light on how and why entrenchment factors are related to the leverage choice of managers. Novaes and Zingales (1995) indicate that debt choice is no longer efficient under entrenched managerial decisions.

Managers are seemingly entrenched to protect themselves from intrinsic and extrinsic corporate governance control instruments, such as supervision by the board, being subjected to takeover threats, or receiving stock-based performance motivation. Entrenched managers manipulate the debt choice to maximize their entrenchment or to retain their terms in office, or both.

Harris and Raviv (1988a) and Stulz (1988) argue that entrenched managers move debt levels beyond the target level to control their voting rights and to hinder takeover threats. In contrast, Jung, Kim, and Stulz (1996) find that debt financing is not given a high priority when firms finance investment. They conclude that entrenched managers tend to issue a large amount of equity, regardless of better alternative outcomes for firm value.

The vital contribution of debt mixed with equity on capital structure has been raised in trade-off theory (Jensen and Meckling, 1976; Jensen 1986), and the pecking order theory (Myers, 1984; Myers and Majluf, 1984). However, these traditional theories have not elaborated on the capital structure choice. The theory of capital structure can be explained with the help of market timing theory.

The market timing theory emphasizes the raising of funds with equity as stock prices increase, and with debt when stock prices fall. Baker and Jeffrey (2002) argue that the capital structure is defined as the cumulative outcome of past attempts to time the equity market.

There are two different versions of equity market timing. First, Myers and Majluf (1984) develop a dynamic-type model based on rational managers and investors, with adverse selection costs fluctuating among different firms or time. Second, it appears that 


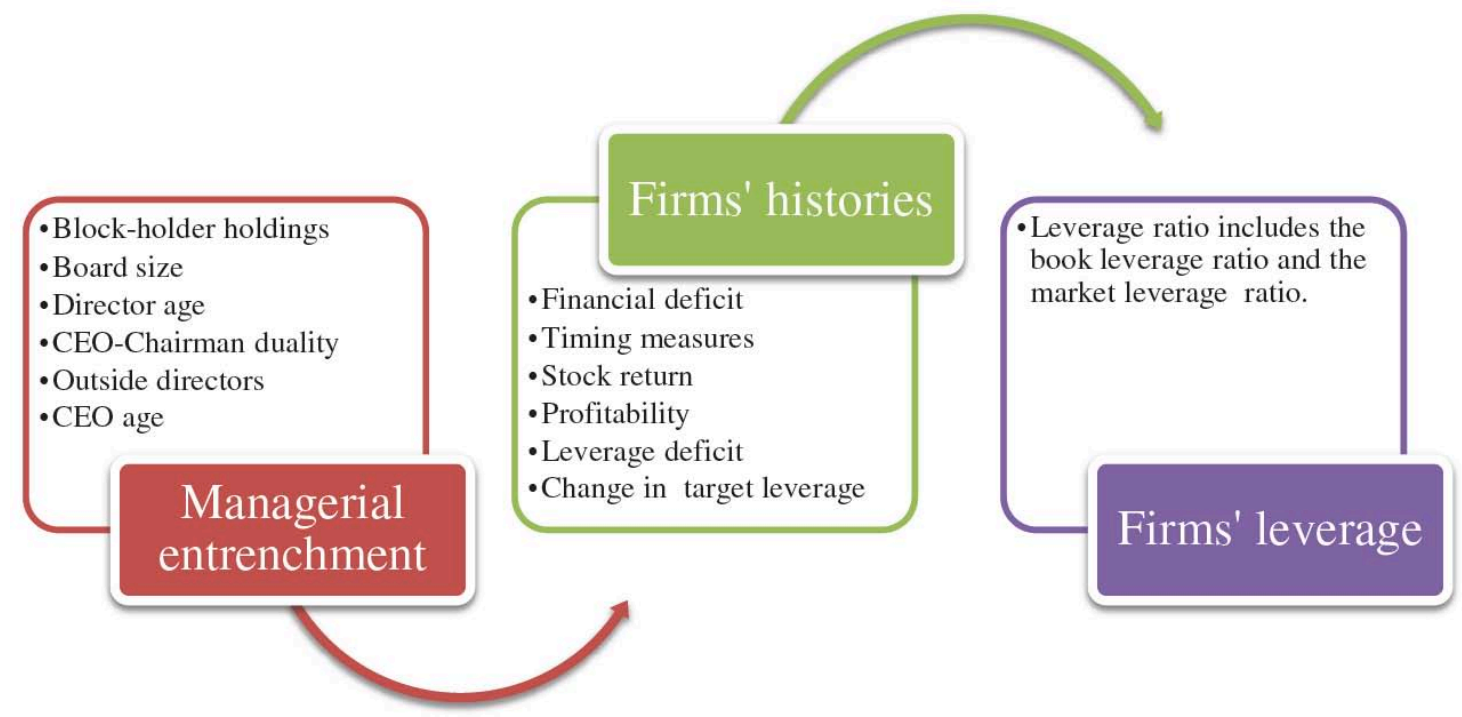

Figure 1: Analytical Framework.

Relationship between managerial entrenchment, firm history and leverage.

equity market timing is used by irrational investors in the belief that they can time the market.

The market does not need to be inefficient and managers do not necessarily follow a trend in stock returns. As a result, market-to-book values do not result from future equity returns, but are related to high expectations of investors (Porta, 1996; Porta et al., 1997; Frankel and Lee 1998).

Bathala, Moon and Rao (1994) and Chen and Steiner (1999) suggest that firms with higher managerial ownership cause a decrease in the debt ratio for fear of high financial distress. Furthermore, Berger, Ofek and Yermack (1997), Novaes and Zingales (1995) and Kayhan (2008) demonstrate that because high-entrenched managers are exposed to an increase in stock prices in relation to the market timing effect, they have a tendency to cut down on debt ratios. Ganiyu and Babalola (2012) confirm that there is a negative influence of managerial entrenchment on the leverage ratio for listed firms in Nigeria and in China (Wen, Rwegasira and Bilderbeek, 2002; Do and Xin, 2013).

Baker and Jeffrey (2002), Kayhan and Titman (2007) and Kayhan (2008) suggest that managers prefer equity to debt for raising external capital in the belief that they can time the equity market. This leads to a reduction in debt financing. Similarly, Law and Chong (2011) suggest that financial deficit negatively affects the leverage ratio of Thai firms.

Based on the timing measurement in Baker and Jeffrey (2002), Kayhan and Titman (2007) separate it into two different types of timing measures, both of which incorporate the vital role of financial deficits, including yearly timing and long-term timing.
Furthermore, Seyhun (1986), Seyhun (1990) and Liu (2009) take advantage of insider sales as an alternative market timing measure. Nonetheless, this market timing variable is insignificant in terms of leverage of US firms.

Graham and Harvey (2001), Hovakimian, Opler, and Titman (2001) and Welch (2004) demonstrate that a decline in stock prices results in the repurchasing of shares. Thus, stock returns tend to have a negative and significant impact on the leverage ratio. In addition, Kayhan and Titman (2007), Kayhan (2008) and Law and Chong (2011) conclude that the leverage ratio is reduced when firms benefit from high market stock returns. The conceptual framework illustrates the simultaneous influence of managerial entrenchment and firm history on the firms' leverage ratio.

The discussion mentioned above is encapsulated in the analytical framework, as illustrated in Figure 1.

\section{DATA, METHODOLOGY AND MODEL SPECIFICATIONS}

The empirical analysis uses a dataset of 289 non-financial firms collected from Ho Chi Minh Stock Exchange (HOSE) for 2006 - 2017. The secondary dataset is extracted from several sources, such as firms' annual reports and financial statements. All financial firms and banks are eliminated from the sample. Ho Chi Minh City is the commercial capital of Vietnam, and has much larger air traffic volume for both business and tourism.

Unlike other countries in South-East Asia, Vietnam has two major stock exchanges, namely the primary Ho Chi Minh Stock Exchange (HOSE) and the smaller Hanoi Stock Exchange (HSX). 
Although there were plans to merge the two stock exchanges, HOSE and HSX will remain separate under a wholly-owned state company from 2020.

The empirical analysis is conducted in the following three steps. First, by using Ordinary Least Squares (OLS), a two-stage approach is used to:

(i) determine the target leverage level; and

(ii) estimate two independent variables, such as the leverage deficit, and the change in target leverage, and to quantify the influence of the managerial entrenchment effect and firm history on the firms' leverage ratios.

Second, Generalized Method of Moments (GMM) is used to accommodate the presence of endogeneity caused by the independent endogenous variables, namely financial deficit, heteroskedasticity and autocorrelation. Generalized Method of Moments (GMM) is preferred to Ordinary Least Squares (OLS) because it is efficient and leads to valid statistical inferences (see, for example, Hansen, 1982; Blundell and Bond, 1998; Blundell and Bond, 2000; Roodman, 2009).

Third, the endogenous switching regression method is used to estimate the impact of managerial entrenchment in both high and low regimes, together with firm characteristics on the leverage ratio.

\subsection{Two-Stage Approach for Estimating Target Leverage Ratios}

Ordinary Least Squares (OLS) is used to construct the target leverage:

$$
\begin{gathered}
L_{i t}^{\text {Target }}=\alpha_{0}+\beta_{1} \frac{M}{B}_{i t}+\beta_{2} P P E_{i t}+\beta_{3} E B I T_{i t}+\beta_{4} R \& D_{i t} \\
+\beta_{5} R \& D \text { dummy } \\
+\beta_{6} S E_{i t}+\beta_{7} S I Z E_{i t}+\beta_{8} \text { Industry dummy }+\varepsilon_{i t}
\end{gathered}
$$

where:

$L_{i t}^{\text {Target: }}$ Target leverage level of firm $i$ in year $t=1,2$, $3, \ldots, 9,10$

M/B: Growth opportunities - the market-to-book ratio of firm $i$ in year $t$

PPE: Property, plant and equipment of firm $i$ in year $t$

EBIT: Profitability of firm $i$ in year $t$

$R \& D: \quad$ Research and development expense of firm $i$ in year $t$

SE: $\quad$ Selling expense of firm $i$ in year $t$

SIZE: $\quad$ Firm size of firm $i$ in year $t$.

\subsubsection{Model Specification}

The impact of managerial entrenchment and firm history on the leverage ratio is estimated by Ordinary Least Squares (OLS) and Generalized Method of Moments (GMM). Based on the literature review and previous empirical studies, the book leverage ratio and market leverage ratio represent the dependent variables, while other variables are defined as exogenous variables and are used as instrumental variables to predict the endogenous variable, namely financial deficits.

The model specification for estimating the impact is given as follows:

$$
\begin{gathered}
L_{i t}-L_{i(t-n)}=\alpha_{0}+\beta_{1} M E s_{i(t, t-n)}+\beta_{2} F D_{i(t, t-n)} \\
+\beta_{3} Y T_{i(t, t-n)}+\beta_{4} L T_{i(t, t-n)} \\
+\beta_{5} R_{i(t, t-n)}+\beta_{6} E B I T_{i(t, t-n)}+\beta_{7} L D E F_{i(t, t-n)} \\
+\beta_{8} \Delta T A R G E T_{i(t, t-n)}
\end{gathered}
$$

$+\beta_{9}$ Industry dummy $+\varepsilon_{i t}$

where:

$t=1,2,3, \ldots, 9,10 ; 1 \leq n \leq 9$

$L_{i t}-L_{i(t-n)}$ : Difference in leverage ratio of firm $i$ in year $t, t-n$

FD: $\quad$ Financial leverage of firm $i$ in year $t, t-n$

YT: $\quad$ Yearly timing measure of firm $i$ in year $t$, $t-n$

$L T: \quad$ Long-term timing measure of firm $\mathrm{i}$ in year $\mathrm{t}, \mathrm{t}-\mathrm{n}$,

$R: \quad \quad$ Stock price histories of firm i in year $t, t-n$

MEs: $\quad$ Managerial entrenchment variables of firm $i$ in year $t, t-n$

EBIT: $\quad$ Profitability of firm of firm $i$ in year $t, t-n$

$\quad L D E F: \quad$ Leverage deficit of firm $i$ in year $t, t-n$

$\triangle T A R G E T$ : Change in target leverage of firm $i$ in year $t, t-n$.

\subsection{Endogenous Switching Regression Model}

The endogenous switching regression model is used to estimate endogenous selections, namely the observed managerial characteristics that are correlated and embedded in managerial entrenchment. In addition, the method is used to prevent biased coefficients arising from heteroskedasticity and autocorrelation in the random errors (Maddala, 1986; $\mathrm{Hu}$ and Schiantarelli, 1998; Almeida and Murillo, 2007; Kayhan, 2008). The endogenous switching regression model incorporates three main equations, namely the selection equation and two structural equations. 


\subsubsection{Selection Equation}

The selection equation which pinpoints the high and low entrenchment regimes is given as follows:

Managerial entrenchment ${ }_{i,(t-n)}=Z_{i,(t-n)} \gamma+u_{i,(t-n)}$

where:

Managerial entrenchment is a proxy measuring the ability of managers to pursue their own interests;

and

$Z$ represents managerial characteristics, such as block-holder holdings, board size, director age, CEO-Chairman duality, outside directors on the board, and CEO age.

\subsubsection{Structural Equations for the High and Low Entrenchment Regimes}

The two structural equations demonstrate the relationship between the high and low entrenchment effects, and firm history on the leverage ratios and debt ratios:

$$
\begin{aligned}
& L_{i t}-L_{i,(t-n)}=\beta_{0}^{H i g h}+\beta_{1}^{H i g h} F D_{i,(t, t-n)}+\beta_{2}^{H i g h} Y T_{i,(t, t-n)} \\
& +\beta_{3}^{H i g h} L T_{i,(t, t-n)} \\
& +\beta_{4}^{H i g h} R_{i,(t, t-n)}+\beta_{5}^{H i g h} E B I T_{i,(t, t-n)}+ \\
& \beta_{6}^{H i g h} L D E F_{i(t, t-n)}+\beta_{7}^{H i g h}{ }^{H A R G E T_{i,(t, t-n)}}+\varepsilon_{i t}^{H i g h} \\
& L_{i t}-L_{i,(t-n)} \\
& =\beta_{0}^{\text {Low }}+\beta_{1}^{\text {Low }} F D_{i,(t, t-n)}+\beta_{2}^{\text {Low }} Y T_{i,(t, t-n)} \\
& +\beta_{3}^{\text {Low }} L T_{i,(t, t-n)}+\beta_{4}^{\text {Low }} R_{i,(t, t-n)}+\beta_{5}^{\text {Low }} E B I T_{i,(t, t-n)} \\
& +\beta_{6}^{\text {Low }}{ }^{L D E F_{i(t, t-n)}}+\beta_{7}^{\text {Low }} \text { TARGET }_{i,(t, t-n)}+\varepsilon_{i t}^{\text {Low }}
\end{aligned}
$$

\subsubsection{Measurement of Variables}

The definitions and measurements of all the variables for the empirical analysis are summarized in Table 1.

\section{EMPIRICAL RESULTS}

The descriptive statistics for the sample are summarized in Table 2. On average, the book leverage accounts for 45.20 percent, while the market leverage accounts for 55 percent. The book leverage ratio is quite high in comparison with that of Dutch firms (see Jong and Veld, 2001) and UK corporations (see Florackis and Ozkan, 2009). The market leverage ratio is much higher than that of US firms (see Kayhan, 2008; Liu, 2009) and Thai companies (see Law and Chong, 2011). Consequently, some Vietnam firms are forced to depend heavily on debt financing.

A board is governed by a CEO with an average age of 47. CEO-Chairman duality is maintained ar 38.30 percent. The board comprises 9 directors and 2 outside directors, with an average age of 44 . Block-holders substantially influence board decisions, with a control of 48 percent of the total shares. The financial deficit contributes 29.60 percent. Timing measures, namely yearly timing and long-term timing, are 10.90 percent and 16.50 percent, respectively. An alternative timing measure, namely insider sales, is 3.80 percent. The mean of one-year stock returns is 8.30 percent.

The correlations among the managerial entrenchment proxies are illustrated in Table 3. A large board is controlled by a large number of outside directors (0.505) and block-holders (0.107). In addition, older CEOs on the board (0.307) are assigned the titles of CEO and Chairperson (0.151) contemporaneously.

In Table 4, the correlations among managerial entrenchment, firm history and firm leverage ratio are displayed. Managerial entrenchment proxies have a positive influence on the book leverage ratio, while these variables negatively affect the market leverage ratio. Financial deficit and profitability (EBIT) have a negative impact on the leverage ratio. Equity issuance follows an increase in stock prices.

The measurement of yearly timing and long-term timing is primarily based on the market-to-book value. Increasing market-to-book is considered a superior growth opportunity. Debt financing will be saved for future consideration. Managers choose to lower the debt ratio when the financial deficit increases. The negative correlation between the leverage deficit and leverage ratio demonstrates that an increase in the leverage deficit leads to a decrease in the leverage ratio.

The absence of multicollinearity is revealed in Table 5, with a maximum of Variance Inflation Factor (VIF) is at 3.92 for model with book leverage as dependent variable and is at 3.75 for model with market leverage as dependent variable.

In Table 6, the Wooldridge test for autocorrelation in panel data indicates that the probability of F-statistic is less than 5 percent. Autocorrelation is detected in the model that has the book leverage and market leverage ratio as dependent variable.

The outcomes of the Breusch-Pagan test (sometimes also referred to as the Cook-Weisberg test) for heteroskedasticity is presented in Table 7. The chi-squared test statistic is significant at the 1 percent level of significance. Hence, there is evidence of significant heteroskedasticity in the sample data.

\subsection{Managerial Entrenchment Effect, Firms' Histories and Leverage Ratio}

Table 8 shows the influence of the managerial entrenchment effect and firm history on the leverage 
Table 1: Definition and Measurement of Variables

\begin{tabular}{|c|c|c|}
\hline Variable & Definition & Measurement \\
\hline \multicolumn{3}{|c|}{ Financial characteristics } \\
\hline Book leverage & The book leverage is the ratio of book debt to total assets. & Book leverage $=\frac{\text { Book debt }}{\text { Total assets }}$ \\
\hline \multirow[t]{2}{*}{ Market leverage } & The market leverage is the ratio of book value of debt to & Market leverage $=$ \\
\hline & $\begin{array}{l}\text { the sum of the book value of debt and the market value of } \\
\text { equity. }\end{array}$ & Total assets - Book equity + Market equity \\
\hline \multicolumn{3}{|c|}{ Managerial entrenchment } \\
\hline Five & $\begin{array}{c}\text { The percentage of block-holder holdings (at least } 5 \text { percent } \\
\text { of shareholdings). }\end{array}$ & Five $=\frac{\text { Shareholdings of beneficial investors }}{\text { Shares outstanding }}$ \\
\hline Board size & The number of directors on the boards. & Board size = Ln (Board size) \\
\hline Director age & The logarithm of median age of director on the board. & Director age $=\operatorname{Ln}($ Median director age $)$ \\
\hline $\begin{array}{l}\text { CEO-Chairman } \\
\text { duality }\end{array}$ & $\begin{array}{c}\text { The variable is a dummy variable that equals to } 1 \text { when } \\
\text { CEOs are also the chairman and } 0 \text { as CEOs are not the } \\
\text { chairman. }\end{array}$ & CEO-Chairman duality $=1$ if $\mathrm{CEO}$ is chairman; 0 otherwise \\
\hline $\begin{array}{c}\text { Board } \\
\text { composition }\end{array}$ & $\begin{array}{c}\text { The percentage of number of outside directors on the } \\
\text { board. }\end{array}$ & Board composition $=\frac{\text { Number of outside directors on the board }}{\text { Board size }}$ \\
\hline CEO age & The logarithm of CEO age. & CEO age $=\operatorname{Ln}($ CEO age $)$ \\
\hline \multicolumn{3}{|c|}{ Firm characteristics } \\
\hline Financial deficit & $\begin{array}{l}\text { The ratio between the sum of investment (I), dividends } \\
\text { (DIV), changes in working capital }(\triangle W C) \text {, and net of cash } \\
\text { flow (CF) divided by total assets. }\end{array}$ & $\begin{array}{c}\text { Financial deficit }(\mathrm{FD})= \\
\frac{\text { Investment+Dividends }+\Delta \text { Working capital-Cash flow }}{\text { Total assets }}\end{array}$ \\
\hline Yearly timing & $\begin{array}{l}\text { The yearly timing is the covariance between financial } \\
\text { deficit and market-to-book ratio. }\end{array}$ & $\begin{aligned} \text { Yearly timing }(\mathrm{YT})= & \sum_{\mathrm{s}=0}^{\mathrm{t}-1} \mathrm{FD} *(\mathrm{M} / \mathrm{B})_{\mathrm{s}} / \mathrm{t}-\overline{\mathrm{FD}} * \overline{\mathrm{M} / \mathrm{B}}= \\
& \operatorname{Cov}(\mathrm{FD}, \mathrm{M} / \mathrm{B})\end{aligned}$ \\
\hline Long-term timing & $\begin{array}{l}\text { The long-term timing is formed by comparing one firm's } \\
\text { market-to-book ratio to another firm. }\end{array}$ & $\begin{array}{c}\text { Long-term timing }(\mathrm{LT})=\sum_{\mathrm{s}=0}^{\mathrm{t}-1}(\mathrm{M} / \mathrm{B})_{\mathrm{s}} / \mathrm{t} * \sum_{\mathrm{s}=0}^{\mathrm{t}-1} \mathrm{FD}_{\mathrm{s}} / \mathrm{t}= \\
\overline{\mathrm{M} / \mathrm{B}} * \overline{\mathrm{F} / \mathrm{D}}\end{array}$ \\
\hline \multirow[t]{2}{*}{ Insider sales } & \multirow{2}{*}{$\begin{array}{l}\text { The ratio between the difference of selling shares and } \\
\text { repurchased shares to number of shares at the end of a } \\
\text { year. }\end{array}$} & $\begin{array}{l}\text { Insider sales }{ }_{\mathrm{t}}= \\
\text { Number of selling shares } \mathrm{s}_{t}-\text { Number of repurchased shares } \mathrm{s}_{\mathrm{t}}\end{array}$ \\
\hline & & Number of shares at the end of a fiscal year $t$ \\
\hline Stock returns & $\begin{array}{l}\text { The logarithm of the difference between share price in the } \\
\text { end }\left(P_{1}\right) \text { and the beginning of one financial year }\left(P_{0}\right) \text { plus } \\
\text { dividends (DIV) divided by share price in the beginning of } \\
\text { the year }\left(P_{0}\right) \text {. }\end{array}$ & Stock returns $(R)=\operatorname{Ln}\left(\frac{P_{1}-P_{0}+D I V}{P_{0}}\right)$ \\
\hline Profitability & $\begin{array}{l}\text { The sum of earnings before interest, and taxes (EBIT) } \\
\text { divided by total assets. }\end{array}$ & Profitability $(E B I T)=\frac{\text { EBIT }}{\text { Total assets }}$ \\
\hline Leverage deficit & $\begin{array}{l}\text { The difference between the realized leverage from its } \\
\text { target leverage. }\end{array}$ & Leverage deficit $(L D E F)=L_{i,(t-n)}-L_{i,(t-n)}^{\text {Target }}$ \\
\hline $\begin{array}{l}\text { Change in target } \\
\text { leverage }\end{array}$ & $\begin{array}{l}\text { The difference between the current target leverage ratio } \\
\text { and the previous target leverage ratio. }\end{array}$ & Change in target leverage $(\triangle T$ TARGET $)=\mathrm{L}_{\mathrm{it}}^{\text {Target }}-\mathrm{L}_{\mathrm{i},(\mathrm{t}-\mathrm{n})}^{\text {Target }}$ \\
\hline Industry dummy & Vietnam standard industry codes & Vietnam standard industry codes (VSIC) \\
\hline
\end{tabular}

Table 2: Descriptive Statistics 289 Listed Companies, Ho Chi Minh Stock Exchange, 2006 - 2017

\begin{tabular}{|c|c|c|c|c|c|}
\hline Variables & Obs. & Mean & Std. Dev. & Min & Max \\
\hline \multicolumn{6}{|l|}{ Financial characteristics } \\
\hline Book leverage & 2890 & 0.452 & 0.247 & 0.001 & 0.993 \\
\hline Market leverage & 2890 & 0.550 & 0.338 & 0.003 & 1 \\
\hline \multicolumn{6}{|l|}{ Managerial entrenchment proxies } \\
\hline Block-holder holdings & 2890 & 0.480 & 0.218 & 0.050 & 2.136 \\
\hline Board size & 2890 & 9.584 & 4.078 & 3 & 34 \\
\hline Director age & 2890 & 44.342 & 6.564 & 26 & 62 \\
\hline CEO-Chairman duality & 2890 & 0.383 & 0.486 & 0 & 1 \\
\hline Board composition & 2890 & 2.444 & 2.376 & 0 & 11 \\
\hline CEO age & 2890 & 47.585 & 7.916 & 24 & 72 \\
\hline
\end{tabular}


(Table 2). Continued.

\begin{tabular}{|c|c|c|c|c|c|}
\hline Variables & Obs. & Mean & Std. Dev. & Min & Max \\
\hline \multicolumn{6}{|l|}{ Firm characteristics } \\
\hline Financial deficit & 2890 & 0.296 & 1.383 & -42.821 & 47.978 \\
\hline Yearly timing & 2890 & 0.109 & 0.006 & -1.505 & 2.972 \\
\hline Long-term timing & 2890 & 0.165 & 0.202 & -3.137 & 3.522 \\
\hline One-year stock returns & 2890 & 0.083 & 1.957 & -39.022 & 2.955 \\
\hline EBIT book & 2890 & 0.083 & 0.100 & -0.647 & 0.987 \\
\hline EBIT market & 2890 & 0.154 & 0.582 & -2.196 & 10.472 \\
\hline
\end{tabular}

Table 3: Correlations for Managerial Entrenchment Proxies

\begin{tabular}{|c|c|c|c|c|c|}
\hline & Five & Board size & Director age & Duality & Outside director \\
\hline \hline Five & 1.000 & & & & \\
\hline Board size & 0.107 & 1.000 & & & \\
\hline Director age & 0.086 & -0.087 & 1.000 & & \\
\hline Duality & -0.193 & -0.015 & -0.200 & 1.000 & -0.114 \\
\hline Outside directors & 0.120 & 0.505 & -0.125 & 0.151 & 1.000 \\
\hline CEO age & 0.021 & 0.037 & 0.447 & -0.097 \\
\hline
\end{tabular}

Table 4: Correlations for Managerial Entrenchment Firm History and Leverage Ratios

\begin{tabular}{|c|c|c|}
\hline Variables & Book leverage \\
\hline \hline Managerial entrenchment variables & 0.024 & 0.007 \\
\hline Block-holder holdings & 0.062 & -0.010 \\
\hline Board size & 0.078 & -0.026 \\
\hline Director age & 0.061 & 0.035 \\
\hline CEO-Chairman duality & 0.013 & -0.008 \\
\hline Outside directors & 0.071 & -0.011 \\
\hline CEO age & & -0.306 \\
\hline Firm characteristics leverage \\
\hline Financial deficit & -0.209 & -0.032 \\
\hline Yearly timing & -0.004 & -0.094 \\
\hline Long-term timing & -0.087 & -0.115 \\
\hline Stock returns & -0.025 & -0.190 \\
\hline EBIT & -0.235 & -0.765 \\
\hline Leverage deficit & -0.834 & 0.554 \\
\hline Change in target leverage & 0.604 & -0.505 \\
\hline
\end{tabular}

Source: Calculations in this paper.

ratio using the Generalized Method of Moments (GMM) method. Timing measures include yearly timing and long-term timing. A large board which is governed by older directors and older CEOs, together with the CEO-Chairman duality, decides to reduce the book leverage ratio. Unlike the managerial entrenchment effect from the book debt ratio, the more the block-holders and outside directors appear in larger boards, the lower is the determination of the market leverage ratio. Financial deficit has a negative impact on the leverage ratio. This empirical finding implies that when firm investment exceeds internal cash flows, managers restrict firms from inducing the debt ratio.

Profitability (EBIT) leads to a decrease in the leverage ratio, meaning that firms use retained 
Table 5: Variance Inflation Factors (VIF)

\begin{tabular}{|c|c|c|}
\hline Variables & VIF - Book leverage & VIF - Market leverage \\
\hline Block-holder holdings & 2.50 & 2.51 \\
\hline Board size & 3.80 & 3.75 \\
\hline Director age & 3.39 & 2.68 \\
\hline CEO-Chairman duality & 1.55 & 1.55 \\
\hline Outside directors & 1.44 & 1.44 \\
\hline CEO age & 3.28 & 3.65 \\
\hline Financial deficit & 1.60 & 1.59 \\
\hline Yearly timing & 2.07 & 2.05 \\
\hline Long-term timing & 2.01 & 2.01 \\
\hline Insider sales & 1.49 & 1.47 \\
\hline EBIT & 1.17 & 1.12 \\
\hline Leverage deficit & 2.50 & 1.10 \\
\hline Change in target leverage & 3.92 & 1.97 \\
\hline
\end{tabular}

Source: Calculations in this paper.

Table 6: Wooldridge Test for Autocorrelation

\begin{tabular}{|c|c|c|}
\hline \multicolumn{2}{|c|}{ Book leverage } & Market leverage \\
\hline \hline F-statistic (1, 288) & 123.299 & F-statistic (1, 288) \\
\hline Prob. F-statistic & 0.000 & Prob. F-statistic \\
\hline
\end{tabular}

Table 7: Breusch-Pagan Test for Heteroskedasticity

\begin{tabular}{|c|c|c|c|}
\hline \multicolumn{2}{|c|}{ Book leverage } & \multicolumn{2}{c|}{ Market leverage } \\
\hline \hline Chi-squared & 367.700 & Chi-squared & 179.150 \\
\hline Prob. Chi-squared & 0.000 & Prob. Chi-squared & 0.000 \\
\hline
\end{tabular}

earnings from profitability to finance the need for investment and to pay for debts borrowed in the past. The market timing proxies, including yearly timing, long-term timing and stock returns, have a negative effect on the leverage ratio. This empirical evidence supports the market timing behaviour of firms.

When stock returns rise, firm tend to issue equity rather than debt financing. Yearly timing and long-term timing are formed by the firm's market-to-book ratio. Higher market-to-book is related to better growth opportunities, and a reduction in the financial deficit. Managers prefer issuing equity over debt. Increasing yearly-timing leads to a reduction in the book debt ratio.

In Table 9, the relationships between managerial entrenchment, firm characteristics and the leverage ratio are displayed. An alternative timing measure, namely insider sales, is substituted for yearly timing and long-term timing. Directors and dual position CEOs with longer working years avoid increasing the book debt ratio. A decline in the market debt ratio is controlled by the presence of block-holders and outside directors on large boards. Financial deficit and profitability (EBIT) have a statistically negative impact on the leverage ratio.

This empirical evidence indicates that internal funds from profitability are preferred over external resources from debt financing when firms finance investments. Firms time the market because insider sales and stock returns negatively affect the leverage ratio. The higher are stock prices, the more will insider transactions managers trade (Seyhun, 1986). This empirical finding implies that equity issuance is preferred to debt financing. In addition, when stock returns increase, shares will appear to be more attractive to investors. Managers decide to issue equity rather than debt financing.

\subsection{Influence of Managerial Entrenchment in both High and Low Entrenchment Regime and Firms' Histories on Leverage Ratio}

Table 10 shows the endogenous switching regressions of the impacts of the high and low 
Table 8: GMM for Leverage Ratio with Yearly Timing and Long-Term Timing

\begin{tabular}{|c|c|c|}
\hline Variables & GMM - Book & GMM - Market \\
\hline Constant & $2.149^{* * *}$ & $-18.19^{* * *}$ \\
\hline Five & -0.0939 & $-4.982^{*}$ \\
\hline Board size & $-1.093^{* * *}$ & $-1.824^{* *}$ \\
\hline Director age & $-7.136^{* * *}$ & -3.003 \\
\hline CEO-Chairman duality & $-1.651^{\star *}$ & -1.418 \\
\hline Outside directors on the board & -0.0205 & $-0.608^{* * *}$ \\
\hline CEO age & $-7.759^{* * *}$ & -2.061 \\
\hline Financial deficit & $-0.124^{* * *}$ & $-1.773^{\star \star \star}$ \\
\hline Yearly timing & $-5.034^{* * *}$ & $-29.55^{\star * *}$ \\
\hline Long-term timing & $-4.533^{* * *}$ & -1.737 \\
\hline Stock returns & $-0.298^{* * *}$ & -0.141 \\
\hline EBIT & -0.441 & $-6.428^{* * *}$ \\
\hline Leverage deficit & $-69.86^{* * *}$ & $-85.03^{* * *}$ \\
\hline Change in target leverage & $29.71^{* * *}$ & $106.6^{* * *}$ \\
\hline Industry dummy & Yes & Yes \\
\hline \multicolumn{3}{|l|}{ Test for validity of instruments } \\
\hline Arellano-Bond test for AR (1): Prob. z-statistic & 0.000 & 0.000 \\
\hline Arellano-Bond test for AR (2): Prob. z-statistic & 0.915 & 0.089 \\
\hline Sargan test: Prob. chi-squared & 0.790 & 0.127 \\
\hline
\end{tabular}

Table 9: GMM for Leverage Ratio with Insider Sales

\begin{tabular}{|c|c|c|}
\hline Variables & GMM - Book & GMM - Market \\
\hline Constant & $1.931^{* *}$ & $-18.01^{* * *}$ \\
\hline Five & -0.102 & $-6.052^{* *}$ \\
\hline Board size & $-1.203^{* * *}$ & $-1.535^{\star}$ \\
\hline Director age & $-7.339 * * *$ & -2.327 \\
\hline CEO-Chairman duality & $-1.974^{* *}$ & -0.615 \\
\hline Outside directors on the board & -0.0246 & $-0.541^{* \star *}$ \\
\hline CEO age & $-8.349^{* * *}$ & -0.970 \\
\hline Financial deficit & $-0.161^{* * *}$ & $-2.690^{*}$ \\
\hline Insider sales & $-0.503^{\star *}$ & $-1.096^{* * *}$ \\
\hline Stock returns & $-0.163^{*}$ & $-0.538^{*}$ \\
\hline EBIT & -1.123 & $-5.927^{* *}$ \\
\hline Leverage deficit & $-68.81^{* * *}$ & $-63.13^{* * *}$ \\
\hline Change in target leverage & $32.00^{* * *}$ & $103.4^{* * *}$ \\
\hline Industry dummy & Yes & Yes \\
\hline \multicolumn{3}{|l|}{ Test for validity of instruments } \\
\hline Arellano-Bond test for AR (1): Prob. z-statistic & 0.000 & 0.000 \\
\hline Arellano-Bond test for AR (2): Prob. z-statistic & 0.953 & 0.400 \\
\hline Sargan test: Prob. chi-squared & 0.912 & 0.433 \\
\hline
\end{tabular}

managerial entrenchment regimes and firm history on the book leverage ratio and market leverage ratio. Timing measures include yearly timing and long-term timing. The empirical results show that the high managerial entrenchment regime includes a larger number of block-holders (Five), larger boards, older CEOs with CEO-Chairman duality and a larger number of outside directors. In Panel $A$, financial deficit and profitability (EBIT) have a negative effect on the book debt ratio in the low entrenchment regime. Similarly, timing measures, namely yearly timing and long-term timing, negatively affect book the leverage ratio in the low entrenchment regime.

However, stock returns have a strong impact on a decline in the book leverage ratio for both the high and low managerial entrenchment regimes. The decline in the book leverage ratio in the high entrenchment regime is higher than in its low entrenchment regime counterpart. From Panel $B$, the negative relationship of 
Table 10: Endogenous Switching for the Leverage Ratio with Yearly Timing and Long-term Timing

Panel A - Book Leverage Ratio

\begin{tabular}{|c|c|c|c|c|c|c|c|}
\hline $\begin{array}{l}\text { Selection } \\
\text { equation }\end{array}$ & Five & $\begin{array}{l}\text { Board } \\
\text { size }\end{array}$ & Director age & $\begin{array}{c}\text { CEO - Chainman } \\
\text { duality }\end{array}$ & $\begin{array}{l}\text { Outside } \\
\text { director }\end{array}$ & CEO age & \\
\hline & $0.405^{\star \star \star *}$ & $0.628^{\star * *}$ & -0.261 & $0.745^{\star \star \star}$ & $0.0542^{* \star *}$ & $0.640^{* \star *}$ & \\
\hline & $(0.143)$ & $(0.065)$ & $(0.212)$ & $(0.073)$ & $(0.0163)$ & $(0.214)$ & \\
\hline $\begin{array}{l}\text { Structural } \\
\text { equation }\end{array}$ & $\begin{array}{c}\text { Financial } \\
\text { deficit }\end{array}$ & $\begin{array}{l}\text { Yearly } \\
\text { timing }\end{array}$ & $\begin{array}{l}\text { Long-term } \\
\text { timing }\end{array}$ & Stock returns & EBIT & $\begin{array}{l}\text { Leverage } \\
\text { deficit }\end{array}$ & $\begin{array}{c}\text { Change in target } \\
\text { leverage }\end{array}$ \\
\hline \multirow{2}{*}{$\begin{array}{c}\text { High } \\
\text { entrenchment }\end{array}$} & 0.0365 & 2.414 & -1.303 & $-0.543^{\star \star *}$ & -3.407 & $-46.54^{\star \star *}$ & $60.40^{* * *}$ \\
\hline & $(0.250)$ & $(4.739)$ & $(2.735)$ & $(0.206)$ & (3.631) & (1.989) & (3.345) \\
\hline \multirow{2}{*}{$\begin{array}{l}\text { Low } \\
\text { entrenchment }\end{array}$} & $-0.519^{\star *}$ & $-7.901^{* *}$ & $-5.166^{\star *}$ & $-0.500^{* *}$ & $-5.968^{\star \star}$ & $-62.58^{* * *}$ & $36.21^{* * *}$ \\
\hline & $(0.231)$ & (3.509) & (2.009) & $(0.221)$ & (3.021) & $(1.462)$ & $(2.171)$ \\
\hline
\end{tabular}

Panel B - Market Leverage Ratio

\begin{tabular}{|c|c|c|c|c|c|c|c|}
\hline $\begin{array}{l}\text { Selection } \\
\text { equation }\end{array}$ & Five & $\begin{array}{l}\text { Board } \\
\text { size }\end{array}$ & Director age & $\begin{array}{c}\text { CEO - Chainman } \\
\text { duality }\end{array}$ & $\begin{array}{l}\text { Outside } \\
\text { director }\end{array}$ & CEO age & \\
\hline & $0.799^{* \star *}$ & $0.608^{\star * *}$ & $-0.344^{*}$ & $0.762^{\star * *}$ & $0.0534^{* * *}$ & $0.685^{\star * *}$ & \\
\hline & $(0.158)$ & $(0.061)$ & $(0.198)$ & $(0.073)$ & $(0.0153)$ & $(0.199)$ & \\
\hline $\begin{array}{l}\text { Structural } \\
\text { equation }\end{array}$ & $\begin{array}{c}\text { Financial } \\
\text { deficit }\end{array}$ & $\begin{array}{l}\text { Yearly } \\
\text { timing }\end{array}$ & $\begin{array}{l}\text { Long-term } \\
\text { timing }\end{array}$ & Stock returns & EBIT & $\begin{array}{l}\text { Leverage } \\
\text { deficit }\end{array}$ & $\begin{array}{c}\text { Change in target } \\
\text { leverage }\end{array}$ \\
\hline \multirow{2}{*}{$\begin{array}{c}\text { High } \\
\text { entrenchment }\end{array}$} & $-1.212^{* * *}$ & $-35.03^{* * *}$ & $-7.631^{* *}$ & -0.133 & $5.819^{* \star *}$ & $-66.88^{* * *}$ & $111.0^{* * *}$ \\
\hline & $(0.312)$ & (6.101) & (3.253) & $(0.291)$ & $(0.741)$ & (2.148) & $(1.869)$ \\
\hline \multirow{2}{*}{$\begin{array}{c}\text { Low } \\
\text { entrenchment }\end{array}$} & $-0.935^{\star \star \star}$ & $-23.96^{\star * *}$ & $-3.372^{* *}$ & -0.172 & $9.609^{\star \star *}$ & $-59.74^{\star * *}$ & $105.4^{* * *}$ \\
\hline & $(0.322)$ & $(5.894)$ & (3.276) & $(0.338)$ & $(0.840)$ & $(2.360)$ & $(1.656)$ \\
\hline
\end{tabular}

the financial deficit and market leverage ratio is much higher in the high entrenchment regime than in the low entrenchment regime. Yearly timing that causes a decrease in the market leverage ratio is greater in the high entrenchment regime than in the low entrenchment regime. Long-term timing has a negative effect on the market leverage ratio in the high entrenchment regime, as compared with the influence in the low entrenchment regime.

Table 11 presents the endogenous switching regressions of the influence of high and low managerial entrenchment and firm history on the leverage ratio. The insider sales variable is substituted for yearly timing and long-term timing. In the market leverage estimation, the high managerial entrenchment regime includes the major presence of block-holders on boards, larger sizes of the board of directors, CEOs with accumulated working years and dual positions, older directors, and more outside directors on boards. The leverage ratio in the high entrenchment regime is strongly influenced by financial deficit and insider sales. An increase in insider trading results in decreases in the market debt level in the high entrenchment regime.

\section{CONCLUSIONS AND POLICY IMPLICATIONS}

Ho Chi Minh City is the commercial and financial capital of Vietnam. Unlike other countries in South-East Asia, Vietnam has two major stock exchanges, namely the primary Ho Chi Minh Stock Exchange (HOSE) and the smaller Hanoi Stock Exchange (HSX). The empirical analysis was based on a sample of 289 non-financial firms listed on Ho Chi Minh Stock Exchange for the period 2006-2017,

The paper provided two major empirical findings to fill the following gaps in current research on corporate governance in Vietnam. For the first time in Vietnam, the effect of corporate governance, managerial entrenchment, together with market timing behaviour on the leverage ratio, have been considered. Second, the impact of managerial entrenchment on the firm leverage ratio is classified into two distinct regimes, including high entrenchment and low entrenchment regimes. Several econometric techniques, namely Ordinary Least Squares (OLS), Generalized Method of Moments (GMM), and endogenous switching regression methods, have been used.

The key empirical findings from the paper can be summarized as below. First, the empirical evidence indicates that there is a negative relationship between managerial entrenchment and the leverage ratio. Second, the empirical results demonstrate a negative effect of firm history, including the financial deficit and various timing measures, together with the stock price history on the leverage ratio of Vietnam listed firms. Third, the impact of the high and low managerial entrenchment regimes and firm history on the book 
Table 11: Endogenous Switching for the Leverage Ratio with Insider Sales

Panel A - Book Leverage Ratio

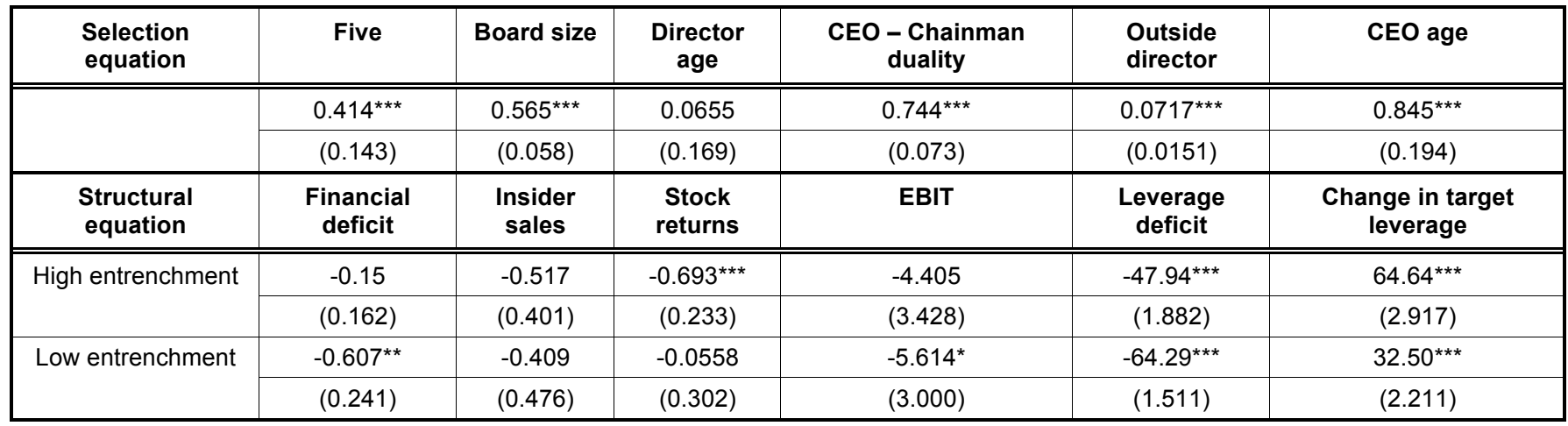

Panel B - Market Leverage Ratio

\begin{tabular}{|c|c|c|c|c|c|c|}
\hline $\begin{array}{l}\text { Selection } \\
\text { equation }\end{array}$ & Five & Board size & $\begin{array}{l}\text { Director } \\
\text { age }\end{array}$ & $\begin{array}{c}\text { CEO - Chainman } \\
\text { duality }\end{array}$ & $\begin{array}{l}\text { Outside } \\
\text { director }\end{array}$ & CEO age \\
\hline & $0.477^{* *}$ & $0.389^{* * *}$ & $0.456^{*}$ & $0.650^{* * *}$ & $0.0473^{* * *}$ & $0.476^{\star * *}$ \\
\hline & $(0.208)$ & $(0.050)$ & $(0.259)$ & $(0.116)$ & $(0.014)$ & $(0.169)$ \\
\hline $\begin{array}{l}\text { Structural } \\
\text { equation }\end{array}$ & $\begin{array}{l}\text { Financial } \\
\text { deficit }\end{array}$ & $\begin{array}{l}\text { Insider } \\
\text { sales }\end{array}$ & $\begin{array}{l}\text { Stock } \\
\text { returns }\end{array}$ & EBIT & $\begin{array}{l}\text { Leverage } \\
\text { deficit }\end{array}$ & $\begin{array}{c}\text { Change in target } \\
\text { leverage }\end{array}$ \\
\hline High entrenchment & $(3.257)$ & $(1.377)$ & $(0.559)$ & $(1.219)$ & $(4.505)$ & $(4.435)$ \\
\hline \multirow[t]{2}{*}{ Low entrenchment } & $-1.372^{* * *}$ & $-2.635^{\star *}$ & $-1.529^{*}$ & $10.85^{\star \star \star}$ & $-54.53^{* * *}$ & $97.70^{* \star *}$ \\
\hline & $(0.530)$ & $(1.144)$ & $(0.819)$ & $(1.301)$ & $(3.866)$ & $(2.569)$ \\
\hline
\end{tabular}

leverage ratio and market leverage ratio was found. Fourth, the results show that the high managerial entrenchment regime is connected to a larger number of block-holders, larger boards, older CEOs, with CEO-Chairman duality and more outside directors.

The implications of the paper are relevant to investors and firms that are listed in Vietnam. A high authority of entrenched managers to the board could be linked to weak corporate governance in Vietnam. The presence of block-holders has no bearing on or benefit to the principal corporate decisions, a large board is not considered as an effective management due to widening agency conflicts, and the ability of outside directors to access a firm's valuable information is limited.

In addition, firms with weak corporate governance could curb their debt levels from increasing by carefully choosing their investment projects. In order to meet investment demands, entrenched managers prefer timing the market by issuing equity after a favourable stock price performance. Nevertheless, equity-oriented governance might deliver an unsafe message to debtholders when value-enhancing risk taking is triggered, leaving these debtholders in financial ruin.

The authors are most grateful to two reviewers for very helpful comments and suggestions. For financial support, the first three authors wish to acknowledge a research grant from Ho Chi Minh City Open University,
Vietnam, and the fourth author is most grateful to the Australian Research Council and Ministry of Science and Technology (MOST), Taiwan.

\section{REFERENCES}

Almeida, H. and Murillo, C. (2007) Financial Constraints, Asset Tangibility, and Corporate Investment, Review of Financial Studies, 20(5), 1429-1460. https://doi.org/10.1093/rfs/hhm019

Baker, M. and Jeffrey W. (2002), Market Timing and Capital Structure, Journal of Finance, 57(1), 1-32. https://doi.org/10.1111/1540-6261.00414

Bathala, C.T., Moon, K.P. and Rao, R. P. (1994), Managerial Ownership, Debt Policy, and the Impact of Institutional Holdings: An Agency Perspective, Financial Management, 23(3), 38-50 https://doi.org/10.2307/3665620

Berger, P.G., Ofek, E. and Yermack, D.L. (1997), Managerial Entrenchment and Capital Structure Decisions, Journal of Finance, 52(4), 1411-1438. https://doi.org/10.1111/j.1540-6261.1997.tb01115.x

Blundell, R. and Bond, S. (2000), GMM Estimation with Persistent Panel Data: An Application to Production Functions, Econometric Reviews, 19(3), 321-340. https://doi.org/10.1080/07474930008800475

Blundell, R. and Bond, S. (1998), Initial Conditions and Moment Restrictions in Dynamic Panel Data Models, Journal of Econometrics, 87(1), 115-143. https://doi.org/10.1016/S0304-4076(98)00009-8

Chen, C.R. and Steiner, T.L. (1999), Managerial Ownership and Agency Conflicts: A Nonlinear Simultaneous Equation Analysis of Managerial Ownership, Risk Taking, Debt Policy, and Dividend Policy, Financial Review, 34(1), 119-136. https://doi.org/10.1111/j.1540-6288.1999.tb00448.x

Jong, A.D. and Veld, C. (2001), An Empirical Analysis of Incremental Capital Structure Decisions under Managerial Entrenchment, Journal of Banking and Finance, 25(10), 1857-1895. https://doi.org/10.1016/S0378-4266(00)00163-1 
Florackis, C. and Ozkan, A. (2009), Managerial Incentives and Corporate Leverage: Evidence from the United Kingdom, Accounting \& Finance, 49(3), 531-553.

https://doi.org/10.1111/j.1467-629X.2009.00296.x

Frankel, R. and Lee, C.M.C. (1998), Accounting Valuation, Market Expectation, and Cross-Sectional Stock Returns, Journal of Accounting and Economics, 25(3), 283-319. https://doi.org/10.1016/S0165-4101(98)00026-3

OECD. (2015), G20/OECD Principles of Corporate Governance. Retrieved from: https://www.oecd-ilibrary.org/docserver/9789 264236882-en.pdf?expires $=1556408164 \&$ id $=$ id\&accname $=g$ uest\&checksum=B0F1C88F573064198FD3B6361BA235EF

Ganiyu, Y.O. and Babalola, Y.A. (2012), The Impact of Corporate Governance on Capital Structure Decision of Nigerian Firms, Research Journal in Organizational Psychology \& Educational Studies 1(2), 121-128.

Graham, J.R. and Harvey, C.R. (2001), The Theory and Practice of Corporate Finance: Evidence from the Field, Journal of Financial Economics, 60(2), 187-243. https://doi.org/10.1016/S0304-405X(01)00044-7

Grossman, S.J. and Hart, O. (1983), Corporate Financial Structure and Managerial Incentives. Retrieved from: https://ssrn.com/abstract=578641.

Hansen, L.P. (1982), Large Sample Properties of Generalized Method of Moments Estimators, Econometrica, 50(4), 1029-1054. https://doi.org/10.2307/1912775

Harris, M. and Raviv, A. (1988a), Corporate Control Contests and Capital Structure, Journal of Financial Economics, 20, 55-86. https://doi.org/10.1016/0304-405X(88)90040-2

Hart, O. (1995), Corporate Governance: Some Theory and Implications, Economic Journal, 105(430), 678-689. https://doi.org/10.2307/2235027

Hovakimian, A., Opler, T. and Titman, S. (2001), The Debt-Equity Choice, Journal of Financial and Quantitative Analysis, 36(1), 1-24. https://doi.org/10.2307/2676195

$\mathrm{Hu}, \mathrm{X}$. and Schiantarelli, F. (1998), Investment and Capital Market Imperfections: A Switching Regression Approach Using Us Firm Panel Data, Review of Economics and Statistics, 80(3), 466-479. https://doi.org/10.1162/003465398557564

Jensen, M.C. (1986), Agency Cost of Free Cash Flow, Corporate Finance, and Takeovers, American Economic Review, 76(2), 323-329.

Jensen, M.C. and Meckling, W.H. (1976), Theory of the Firm: Managerial Behavior, Agency Costs and Ownership Structure, Journal of Financial Economics, 3(4), 305-360. https://doi.org/10.1016/0304-405X(76)90026-X

Jung, K., Kim, Y.C. and Stulz, R.M. (1996), Timing, Investment Opportunities, Managerial Discretion, and the Security Issue Decision, Journal of Financial Economics, 42(2), 159-185. https://doi.org/10.1016/0304-405X(96)00881-1

Kayhan, A. (2008), Managerial Discretion and the Capital Structure Dynamics. https://doi.org/10.2139/ssrn.1102880

Kayhan, A. and Titman, S. (2007), Firms' Histories and Their Capital Structures, Journal of Financial Economics, 83(1), 1-32. https://doi.org/10.1016/j.jfineco.2005.10.007

Porta, R.L. (1996), Expectations and the Cross-Section of Stock Returns, Journal of Finance, 51(5), 1715-1742. https://doi.org/10.1111/j.1540-6261.1996.tb05223.x

Porta, R.L., Lakonishok, J., Shleifer. A. and Vishny, R. (2012), Good News for Value Stocks: Further Evidence on Market
Efficiency, Journal of Finance, 52(2), 859-874.

https://doi.org/10.1111/j.1540-6261.1997.tb04825.x

Law, T.Y. and Chong, T.T.L. (2011), Thai Firms' Histories and Their Capital Structure, Annals of Financial Economics, 6(1). https://doi.org/10.1142/S2010495211500047

Liu, L.X. (2009), Historical Market-to-Book in a Partial Adjustment Model of Leverage, Journal of Corporate Finance, 15(5), 602-612.

https://doi.org/10.1016/j.jcorpfin.2009.07.003

Maddala, G.S. (1986), Disequilibrium, Self-Selection, and Switching Models, Handbook of Econometrics 3, 1633-1688. https://doi.org/10.1016/S1573-4412(86)03008-8

Morck, R., Shleifer, A. and Vishny, R.W. (1988), Management Ownership and Market Valuation: An Empirical Analysis, Journal of Financial Economics, 20, 293-315. https://doi.org/10.1016/0304-405X(88)90048-7

Myers, S.C. (1984), The Capital Structure Puzzle, Journal of Finance, 39(3), 574-592. https://doi.org/10.1111/j.1540-6261.1984.tb03646.x

Myers, S.C. and Majluf, N.S. (1984), Corporate Financing and Investment Decisions when Firms have Information that Investors do not have, Journal of Financial Economics, 13(2), 187-221. https://doi.org/10.1016/0304-405X(84)90023-0

Nguyen, N.H.H. (2015), Market timing and capital structure choice: Empirical from Vietnam's listed firms, Journal of Development and Integration, 22(32), 73-77.

Novaes, W. and Zingales. L. (1995), Capital Structure Choice When Managers Are in Control: Entrenchment versus Efficiency. https://doi.org/10.3386/w5384

Roodman, D. (2009), How to Do Xtabond2: An Introduction to Difference and System GMM in Stata, Stata Journal. 9(1), 86-136. https://doi.org/10.1177/1536867X0900900106

Ross, S.A. (1977), The Determination of Financial Structure: The Incentive-Signalling Approach, Bell Journal of Economics, 8(1), 23-40. https://doi.org/10.2307/3003485

Seyhun, H.N. (1990), Do Bidder Managers Knowingly Pay Too Much for Target Firms?, Journal of Business, 63(4), 439-464. https://doi.org/10.1086/296516

Seyhun, H.N. (1986), Insiders' Profits, Costs of Trading, and Market Efficiency, Journal of Financial Economics, 16(2), 189-212. https://doi.org/10.1016/0304-405X(86)90060-7

Stulz, R.M. (1988), Managerial Control of Voting Rights: Financing Policies and the Market for Corporate Control, Journal of Financial Economics, 20, 25-54. https://doi.org/10.1016/0304-405X(88)90039-6

Vo, D.H. and Tran, A.M.N. (2015), Empirical evidence on the Pecking Order Theory from Ho Chi Minh City Stock Exchange, Banking Technology Review, 25, 11-22.

Welch, I. (2004), Capital Structure and Stock Returns, Journal of Political Economy, 112(1), 106-132. https://doi.org/10.1086/379933

Wen, Y., Rwegasira, K. and Bilderbeek, J. (2002), Corporate Governance and Capital Structure Decisions of the Chinese Listed Firms, Corporate Governance: An International Review, 10(2), 75-83. https://doi.org/10.1111/1467-8683.00271

Do, Q.X. and Xin, W.Z. (2014), Impact of Ownership Structure and Corporate Governance on Capital Structure: The Case of Vietnamese Firms, Australian Journal of Business and Management Research, 7(2), 64-71.

\section{DOI: https://doi.org/10.6000/1929-7092.2019.08.70}

(c) 2019 Pham et al.; Licensee Lifescience Global.

This is an open access article licensed under the terms of the Creative Commons Attribution Non-Commercial License (http://creativecommons.org/licenses/by-nc/3.0/) which permits unrestricted, non-commercial use, distribution and reproduction in any medium, provided the work is properly cited. 